\title{
DIATOMS OF THE ANTARCTIC - ENVIRONMENTAL INTERPRETATION OF THE MIDDLE PLIOCENE AT SITE 697
}

EDUARDO CENTENO, Wesleyan University

Research Advisor: Suzanne O’Connell

\section{ABSTRACT}

Understanding the effects of warming events on sea ice during the geologic past is critical for predicting future sea ice behavior. In the last 15 million years (Ma), five major episodes of Southern Ocean diatom species turnover (origination rate plus extinction rate) have been identified and linked to times of cooling and ice expansion. However, the highest turnover rate occurred between 3.55-3.40 Ma and aligns with an increase in biosiliceous activity, rising $\mathrm{CO}_{2}$ concentrations, warming temperature and ice retraction The goal of this application is to determine the mechanisms that catalyzed this anomalous turnover pulse by creating a record of the diatom community in the Weddell Sea off the coast of the Antarctic Peninsula. Preliminary results show that during the 100,000 year period (3.2-3.29 $\mathrm{Ma}$ ), toward the end of MIS M2, Site 697 was marked by open ocean conditions and indicate sea ice conditions were unstable. A more comprehensive dataset will allow us to explore conditions during both MIS M2 and the earlier Turnover Pulse D. We will be able to identify relationships between the two events and discover the mechanisms by which they were catalyzed.

\section{INTRODUCTION}

Diatoms are of critical interest today because they contribute an estimated $45 \%$ of total oceanic primary production (Yool, 2003), they are the dominant living marine phytoplankton group, and their macroevolutionary history is linked to changes in climate (Lazarus, 2014). This important group of microalgae are a common tool for paleoclimate scientists because diatoms are diverse, with estimates of the number of species on the order of 105 (Mann and Droop, 1996). They are also sensitive to environmental conditions and are able to inhabit virtually any environment with moisture and sunlight, making them an especially versatile and accessible paleoclimate indicator (Crosta and Koc, 2007).

One third of the diatoms of the genus Chaetoceros are known to form resting spores within the vegetative cell associated with unfavorable conditions such as nitrogen deficiency and low light conditions (Hargraves and French, 1975, Leventer, 1991). Previous work has not detected a relationship between the abundance of Chaetocerous resting spores and sea surface temperature (Zielinski and Gersonde, 1997). However, high productivity has been shown to be very important to the distribution of Chaetocerous resting spores (Donegan and Schrader, 1982, Leventer, 1991, Karpuz and Jansen, 1992, Zielinski and Gersonde, 1997). Chaetocerous resting spore dominance has been suggested to be catalyzed by surface water stratification produced by sea ice melt water (Leventer et al., 1993, Leventer et al., 1996).

\section{Site 697}

The Ocean Drilling Program (ODP) was an international cooperative effort that conducted 110 expeditions and drilled 2000 drill holes (IODP website). Site 697 is a drill hole located in the Weddell Sea within the Jane Basin and is 3480 meters below sea level. Site 697 is the deepest of a three-site depth transect of the South Orkney microcontinent (SOM) drilled during ODP Leg 113 (Barker, Kennett et al., 1988)[See O’Connell, Fig. 1, this volume].

\section{Southern Ocean Phytoplankton Turnover}

Five major episodes of Southern Ocean diatom species turnover (origination rate plus extinction rate) [Fig. 1] 
have been identified and linked to times of cooling and ice expansion in the last 15 million years (Ma). Figure 1 (Crampton et al., 2016) was created using a model reconstruction of diatom speciation and extinction rates to examine phytoplankton response to climate change in the southern high latitudes over the past $15 \mathrm{My}$. The ages of the five major pulses are approximately $14.65-14.45 \mathrm{Ma}(\mathrm{A}), 13.75-13.55$ Ma (B), 4.90-4.40 Ma (C), 3.55-3.40 Ma (D), and 3.00-1.95 Ma (E) (Crampton et al., 2016). However, it is unclear why the turnover pulse that occurred between 3.55-3.40 Ma (turnover pulse D) - the highest of all five turnover rates - correlates with an increase in biosiliceous activity (Fig. 1, Graph D), rising $\mathrm{CO}_{2}$ concentrations (Fig. 1, Graph E), warming temperature and ice retraction (Fig. 1, Graph C) [Crampton et al., 2016].

\section{Marine Isotope Stage M2}

The Marine Isotope Stage (MIS) M2 (3.312-3.264 Ma) [Tab. 1] was a global glaciation event that corresponded to a 20 to $60 \mathrm{~m}$ sea-level drop (Tan et al., 2017). This glaciation event interrupted the period of global warmth and high $\mathrm{CO}_{2}$ concentration of the mid-Piacenzian (Tan et al., 2017). Unlike the late Quaternary glaciations, $\mathrm{M} 2$ only lasted 50 thousand years and occurred under uncertain $\mathrm{CO}_{2}$ concentration (Tan et al., 2017).

\section{Objective}

The goal of this research study is to determine the mechanisms that catalyzed the turnover pulse that occurred between 3.55-3.40 Ma by creating a record of the diatom community at Site 697. This is a data sparse region that plays a key role in our climate (Salzmann et al., 2011). Diatom species are highly endemic in the Southern Ocean and form two distinct biomes: a specialized flora occupying the sea ice zone (Armand et al., 2005) and a high-nutrient, lowchlorophyll flora occupying the open ocean (Crosta et al. 2005). Past plankton turnover has been inferred to occur when a warmer-than-present climate state is terminated by a major period of glaciation that results in loss of open-ocean habitat due to increase sea ice cover, driving non-ice adapted diatoms to regional or global extinction [Figure 2] (Crampton et al., 2016).
The central hypothesis underpinning this research is that turnover pulse $\mathrm{D}$ was caused by a warming event that decreased ice cover, in turn driving ice adapted diatoms to extinction and non-ice adapted diatoms to rapid speciation. By calculating the relative abundance of sea ice and non-sea ice diatoms through time, we
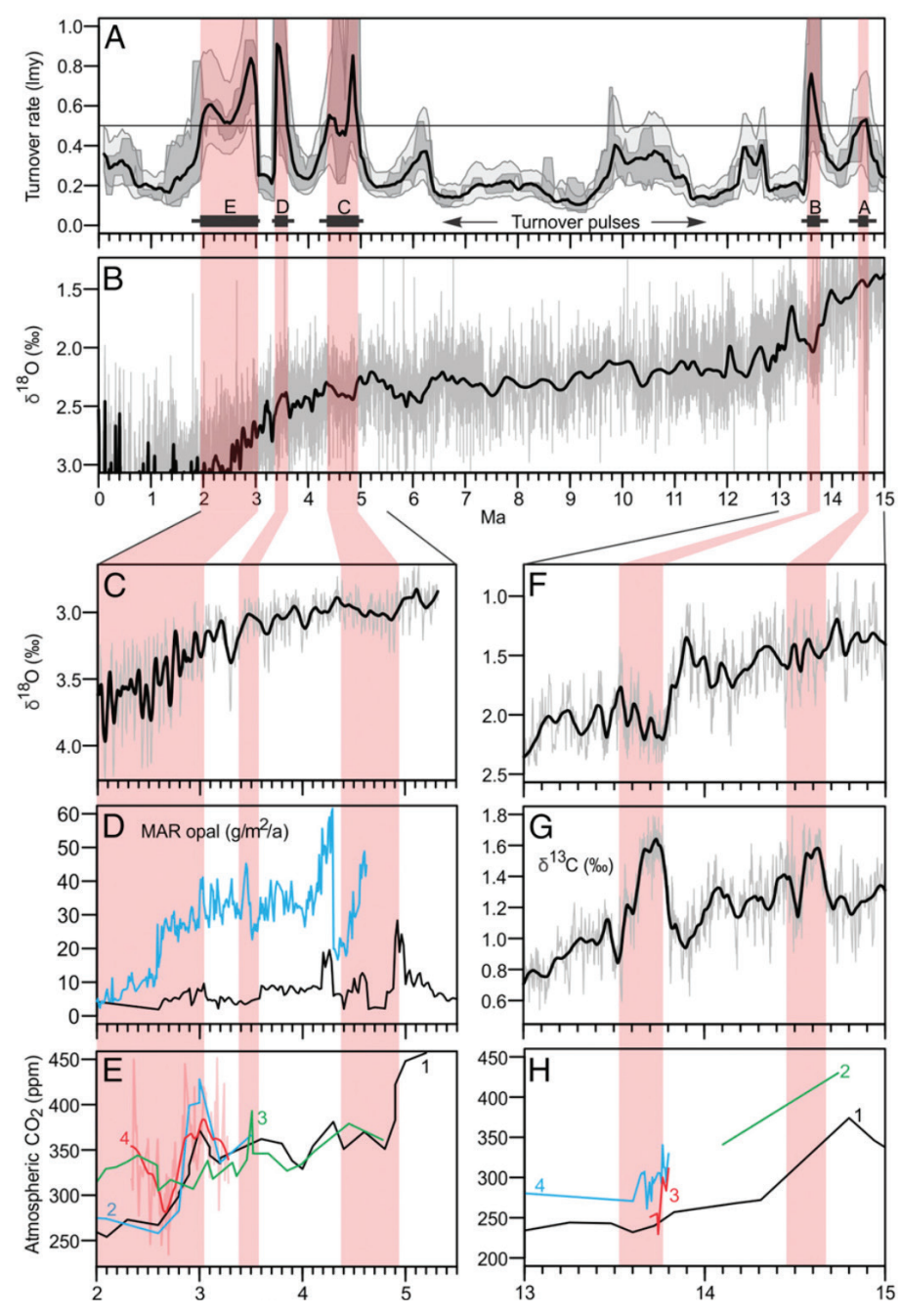

Figure 1. Turnover pulses of diatoms in the Southern Ocean and Antarctic margin over the past 15 Ma compared with key paleoenvironmental proxies. (A) A plot of species lineagemillion-year (Imy) turnover rate, with major pluses identified by pink bars. (B) Benthic $\delta^{18} \mathrm{O}$ curve for the time interval 15-0 Ma. (C) Benthic $\delta^{18} O$ curve for the time interval 5-2 Ma. (D) Opal accumulation rates, which acts as a proxy for sea ice extent on the Antarctic margin for the time interval 5-2 Ma. Declining opal accumulation indicates an expansion in sea ice. (E) Estimate of atmospheric $\mathrm{pCO}_{2}$ for the time interval 5-2 Ma, based on alkenone ( 1 and 2) and boron ( 3 and 4) proxies. (F) Benthic $\delta^{18} O$ curve for the time interval 15-13 Ma. (G) Benthic $\delta^{13} C$ curve for the time interval 15-13 Ma. (H) Estimates of atmospheric $\mathrm{pCO}_{2}$ based on alkenone (2 and 4), boron (1), and $\mathrm{B} / \mathrm{Ca}$ (3) proxies (Crampton et al., 2016). 
Table 1. Table of absolute ages which are calculated for magnetic time scale reversals and corresponded to samples in the 697 core.

\begin{tabular}{|c|c|c|c|c|}
\hline $\begin{array}{c}\text { Magnetic } \\
\text { boundaries }\end{array}$ & Sample & $\begin{array}{c}\text { Depth (meters below } \\
\text { seafloor) }\end{array}$ & $\begin{array}{c}\text { G\&K (2007) model } \\
\text { age (millions of years) }\end{array}$ & $\begin{array}{c}\text { Pudsey (1990) } \\
\text { model age } \\
\text { (millions of years) }\end{array}$ \\
\hline $\begin{array}{c}\text { Matuyama chron, base / } \\
\text { C2AN-1, top }\end{array}$ & $697 \mathrm{~B}-10 \mathrm{H}-1-100$ & 105.7 & 2.608 (LR05) & 2.470 \\
\hline C2AN-2, top & $697 \mathrm{~B}-13 \mathrm{X}-4-8$ & 132.8 & 3.11 & 2.99 \\
\hline C2AN-2, base & $697 \mathrm{~B}-14 \mathrm{X}-1-50$ & 138.7 & 3.22 & 3.08 \\
\hline C2AN-3, top & $697 \mathrm{~B}-14 \mathrm{X}-7-40$ & 147.6 & 3.33 & 3.13 \\
\hline $\begin{array}{c}\text { Gauss chron, base / } \\
\text { C2AN-3, base }\end{array}$ & $697 \mathrm{~B}-16 \mathrm{X}-4-50$ & 162.25 & 3.58 & 3.40 \\
\hline C3N-1, top & $697 \mathrm{~B}-20 \mathrm{X}-4-30$ & 201 & 4.18 & 3.88 \\
\hline
\end{tabular}

Note: Original ages were determine by Pudsey (1990), but were never published. Absolute ages were redeveloped by Gee and Kent (2007) and are the ones used in this study.

can construct a diatom-inferred record of sea ice fluctuation. The relative abundance of sea ice adapted and non-sea ice adapted diatoms is also supplemented by additional data on biosilica weight percent (wt. \%) and course fraction analysis by our research team. Comparing the microfossil abundances to our biosilica wt. $\%$ and course fraction data gives us a holistic perspective with which to consider the causes for turnover pulse D. This information regarding the timing of climatic events and the paleoenvironmental conditions that characterized them (i.e., SST, extent of sea ice, and ice sheet size) are relevant to help constrain paleoclimate and ice sheet models for the early-middle Pliocene.

\section{METHODS}

\section{Sample Collection and Supplementary Data}

Samples for the working half of Site 697 were collected at the Integrated Ocean Discovery Program Core Repository. Excluding areas of the core with poor recovery, 20 cubic centimeters of samples were brought back to the Wesleyan University campus for further study.

For course fraction analysis, samples were washed according to standard wet-sieving procedures. Course fraction is a proxy for melting from land-derived icebergs.

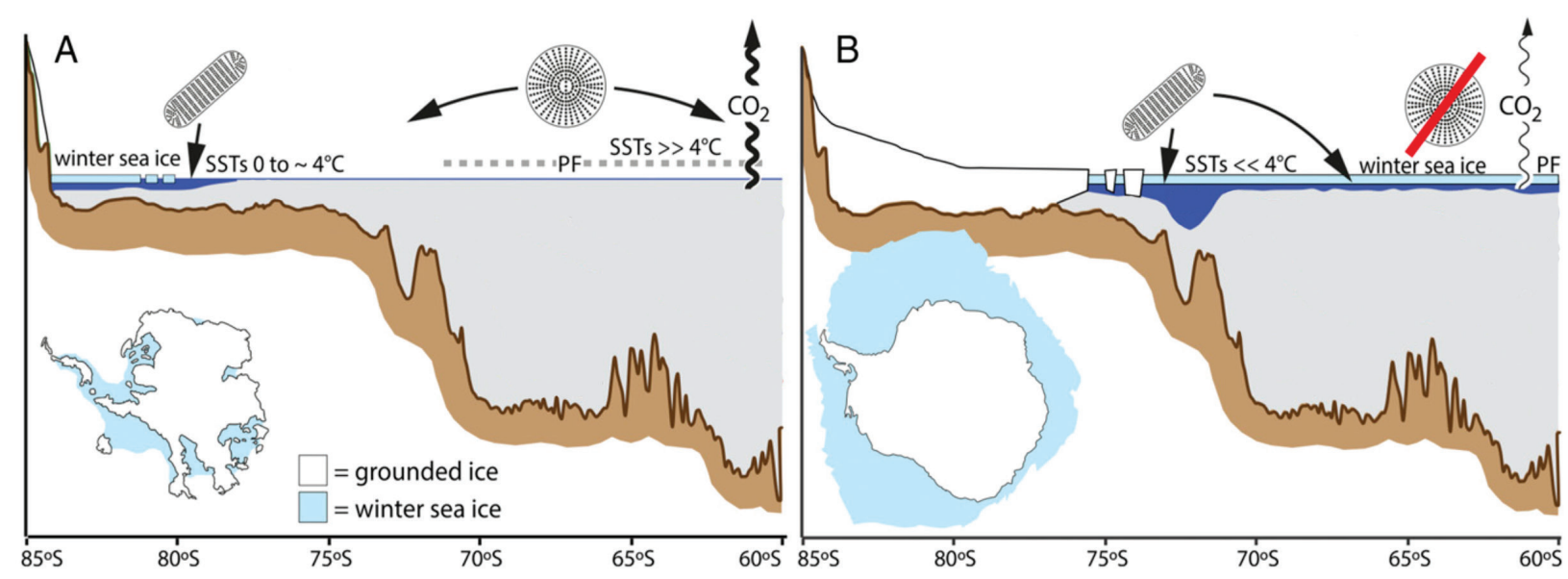

Figure 2. Modified figure from Crampton et al. (2016), showing schematic environmental reconstruction for the Antarctic continental shelf and Southern Ocean during intervals of (A) warmth and ice minimum and (B) peak cold and maximum ice extent. Crampton et al. (2016) hypothesizes that rapid transitions between these two environmental states is the main cause of major species turnover, as it drives extinction/speciation of warm/cold-adapted phytoplankton. Ventilation of $\mathrm{CO}_{2}$-enriched deep water is indicated by wavy arrow (thin line indicates reduced ventilation due to stratified surface water and sea ice cover). PF, polar front. 
Biosilica wt. \% for our samples is determined mostly by diatom abundance, with minor contributions from radiolarians and other siliceous organisms. Therefore, the wt. \% biosilica is a proxy for diatoms, which in turn, are an indicator of productivity in the waters around Site 697.

\section{Preparing Diatom Slides}

For each sample, approximately $0.5 \mathrm{~g}$ of sediment was placed in a desiccator for at least 24 hours to ensure they were completely dry. Next, $0.3 \mathrm{~g}$ of sample is placed in a $50 \mathrm{~mL}$ centrifuge tube and softened in deionized water. The sample is then treated with $20 \mathrm{~mL}$ of $35 \%$ hydrogen peroxide in order to oxidize organic material. After effervescence stops, samples are rinsed multiple times with deionized water and centrifuged at $1500 \mathrm{rpm}$ for 10 minutes. To further disaggregate sediments, samples are treated with a dilute Calgon (sodium hexametaphosphate) solution and later rinsed as described above.

The next step of this procedure uses a random settling method to evenly distribute the diatoms in solution over three quantitative slides per sample. For each sample, $5 \mathrm{~mL}$ of randomized suspended sediment was extracted and added to a small beaker containing $45 \mathrm{~mL}$ of deionized water to allow for good dissemination. The diluted solution was then poured into a petri dish containing $20 \mathrm{~mL}$ of deionized water. After waiting 30 minutes for the sediment to settle in the petri dish, short strips of paper towel were inserted into the water and connected to a sponge under the petri dish. Through capillary action this step drains the water and expedites drying. After allowing for all of the water in the petri dish to dry, coverslips were removed from the petridish, dried on a hot plate, and mounted to glass slides using Norland Optical Adhesive \#61.

\section{Identifying and Counting Diatoms}

One slide per sample was examined under a light microscope at 1,000x magnification. Random traverses are made across the coverslip until at least 500 diatom valves are counted for each sample to ensure an accurate representation of the fossil assemblage (Chang, 1967).
Diatoms were only counted when at least half of a valve was visible. Each diatom was identified to the species level unless diagnostic features were missing, in which case they were categorized at the generic level. Diatoms from the lineolate genera, such as Thalassiothrix and Thalassionema, are usually fractured along its length, in which case two ends counted as one valve. Chatoceros resting spores were included in the results because they are often associated with high levels of productivity in a stratified setting. Environmental preferences were assigned to species according to the findings of Armand et al. (2005) and Crosta et al. (2005)

\section{Age Model}

The ages for this study are based on the reversal stratigraphy given in Pudsey (1990) and then tied to the Gee and Kent (2007) timescale. Between reversals, ages are extrapolated.

\section{Statistical Analysis}

$P$ values and statistical data were collected with the program language R. A chi square test was performed on the data to determine statistical significance.

\section{RESULTS}

\section{Preliminary Data}

Diatom assemblages were characterized for three samples. This study will be continued and we plan to analyze around 100 samples in Site 697 before the end of the calendar year. All three samples were located in section $14 \mathrm{x}$ of the core, between $3.2-3.29 \mathrm{Ma}(\sim 140.4-$ $144.6 \mathrm{mbsf})$. The oldest sample, $14 \mathrm{X}-5,55-57 \mathrm{~cm}$ (sample 1), occurs at the coldest time period of MIS M2 at around 3.29 Ma (Fig. 3). This section in the core is characterized by relatively low biosilica levels ( 5 wt. \%), very low course fraction ( 0-2 wt. \%). Sample $2,14 \mathrm{X}-4,68-70 \mathrm{~cm}$ was deposited around 3.27 Ma, and marks the end of the large peak during the earliest parts of MIS M2. Sample 2 exhibits similar values of biosilica and course fraction wt. \% as Sample 1. Sample 3, 14X-2, 66-68 cm, is the youngest sample analyzed in this study and occurs around 3.2 Ma. Sample 3 contains 11 wt. \% biosilica and a slight increase in course fraction to $3 \mathrm{wt}$. $\%$. 


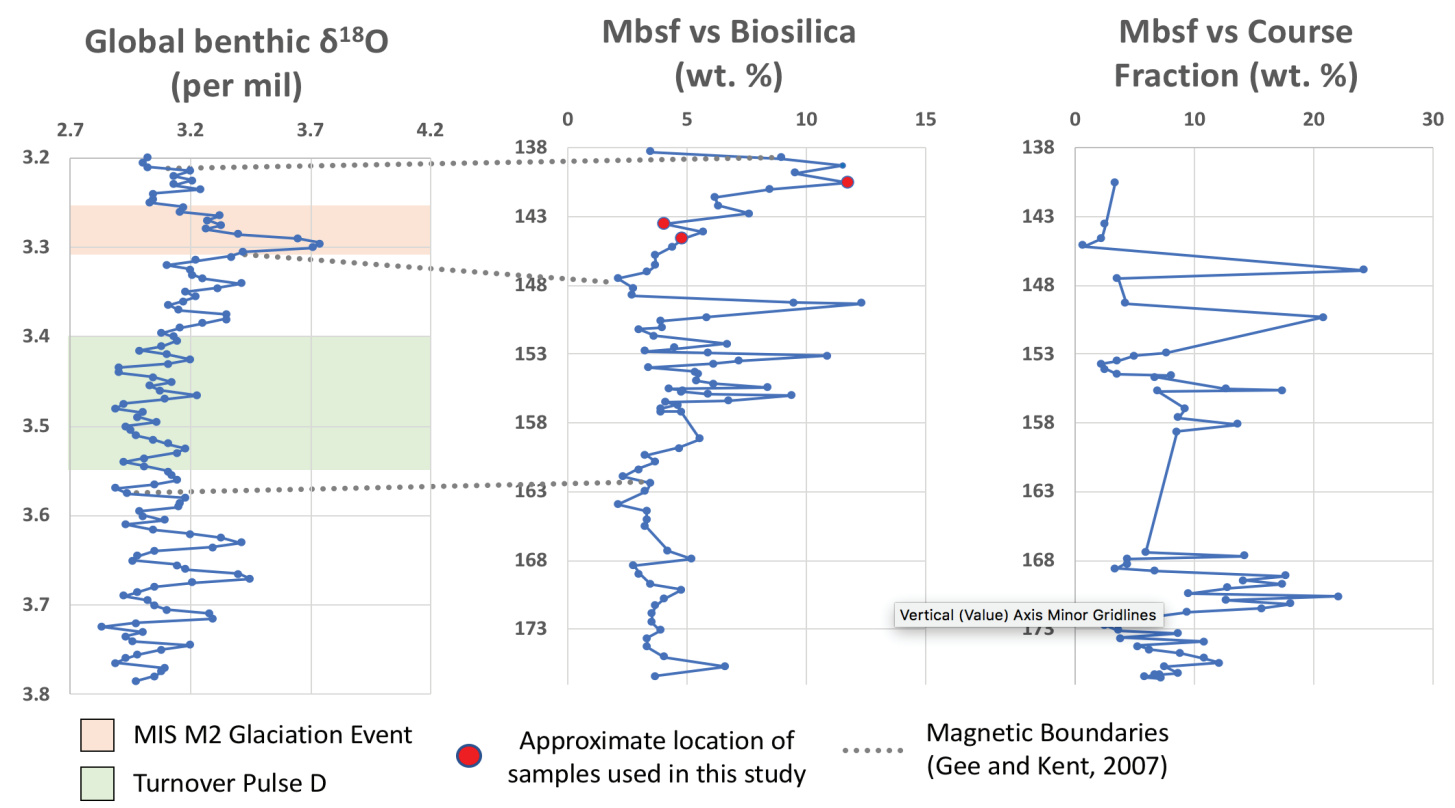

Figure 3. On the left, benthic foraminiferal $\delta^{18} \mathrm{O}$ stack is plotted from $\sim 3.2$ to $3.8 \mathrm{Ma}$ (sections $14 x-17 \mathrm{x}$ in the core), which is an average of 57 globally distributed $\delta^{18} \mathrm{O}$ records (Lisiecki and Raymo, 2005). MIS M2 (3.312-3.264 Ma) is highlighted by an orange box. The event produced $a \sim 0.5 \%$ shift of benthic foraminiferal $\delta^{18} \mathrm{O}$ (Tan et al., 2017). Turnover Pulse D is highlighted by a green box. The graph in the center is a plot of biosilica wt. \% for sections $14 x-17 x$, and serves as a proxy for productivity. The three samples used in this study are denoted by a red dot and tie lines for magnetic boundaries are connected to their corresponding samples by the grey dotted lines. The graph on the right is a plot of course fraction weight \% for sections $14 x-17 x$, and serves as a proxy for sea ice retreat.

\section{Diatom Data}

A diverse assemblage of diatoms was found in the three samples, which incorporated 54 distinct species or species groups. The abundance of representative species is presented as percent of the total assemblage. The complete data set is available on request.

Figure 4 shows similar trends in all the samples with respect to our open ocean and sea ice affinity diatoms. The sea ice diatom assemblage is very small, except for the species Eucampia Antarctica which consistently dominated all three assemblages and had the highest count for any species in the youngest sample.

In sample 1, characteristic species include Thalassiothrix spp. (9.6\%), Chaetoceros resting spores (9.6\%), Eucampia Antarctica (13\%), Fragilariopsis barronii (5.9\%), and Rouxia Antarctica (4\%). Present in low abundances are Rouxia naviculoides (1.7\%), Thalassiosira torokina (1.7\%), and Fragilariopsis sublinearis (0.4\%) (Fig. 4).
In sample 2, dominant species include Rouxia Antarctica $(8.1 \%)$, Rouxia naviculoides $(8.5 \%)$, and Chaetoceros resting spores (11\%) (Fig. 4). Decreasing in abundance are Fragilariopsis barronii (3.3\%), Thalassiothrix spp. (6.6\%), and Eucampia Antarctica (7.9\%). Thalassiosira torokina (1.5\%) and Fragilariopsis sublinearis $(0.4 \%)$ remain in low abundance

In sample 3, the abundance Fragilariopsis barronii (3.1\%), Rouxia Antarctica (9.7\%), Rouxia naviculoides (3.9\%), Thalassiothrix spp. (5.2\%), Chaetoceros resting spores (5.4\%) decreases, while Eucampia Antarctica increases to $15 \%$. Fragilariopsis sublinearis $(1.2 \%)$ increases slightly in this sample but remains in low abundance. Thalassiosira torokina $(1.2 \%)$ remains in low abundance (Fig. 4).

\section{DISCUSSION}

The low wt.\% biosilica and wt.\% course fraction data from Samples 1 and 2 seem to suggest a cold period marked by low productivity and stable ice covered conditions. These data are consistent with the global benthic $\delta^{18} \mathrm{O}$ data that show very fast cooling during 


\section{Diatom Relative Abundance (\%)}

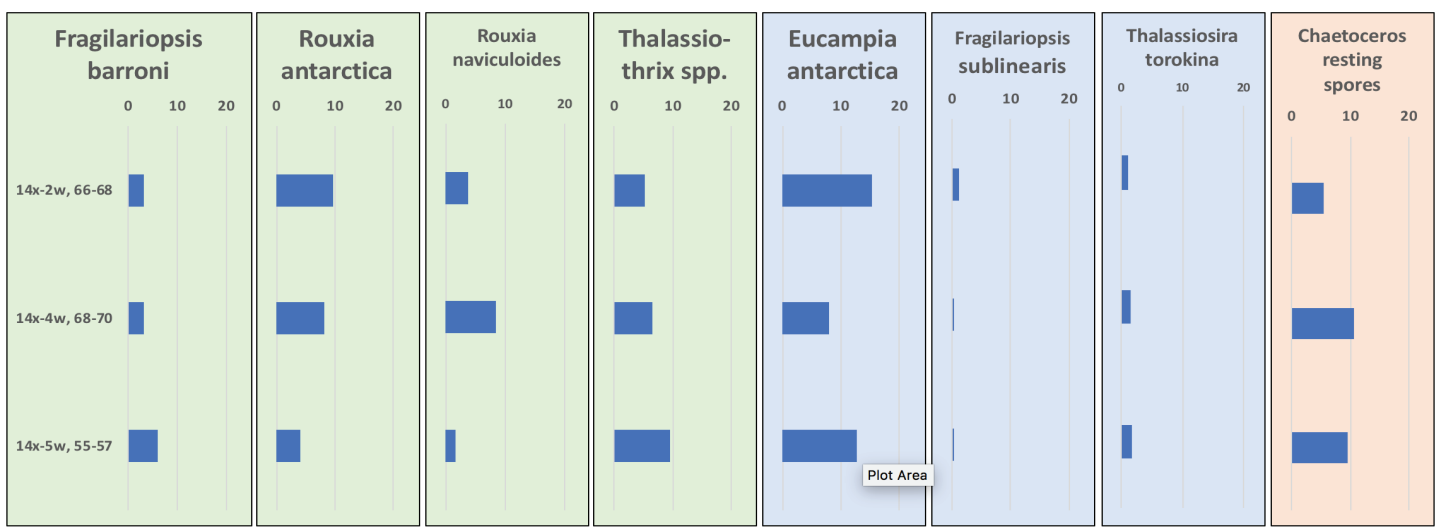

open ocean/ ice tolerant

sea ice affinity

high productivity or stratification

Figure 4. Relative abundance of select Site 697 diatom species. Environmental preferences were assigned using information from Crosta et al. (2005) and Armand et al. (2005). Open ocean/ice tolerant species are highlighted in green. Diatom species with a sea ice affinity are highlighted in blue. Diatom species associated with high productivity or stratification are highlighted in orange.

this time (Lisiecki and Raymo, 2005). However, these samples are also characterized by high values of Chaetocerous resting spores ( 9.6 and $11 \%$, respectively) often associated with high productivity in a stratified setting. Heavily silicified diatom resting spores have a faster sinking rate than vegetative cells and are therefore less vulnerable to dissolution (Mcquoid and Hobson, 1996). A preservation bias might be responsible for the high counts of resting spores that we see in our data. The count data for Chaetocerous resting spores was determined to be statistically significant ( $\mathrm{p}$ value of 0.009).

Chaetocerous counts for Sample 3 are lower than expected, which suggests that an environment change that made it less conducive to the growth of this species even though there is a $6 \%$ increase in biosilica wt. $\%$ and a slight increase in course fraction. This time interval also occurs during the late warming period of MIS M2. These data suggest this warming period saw a decrease in ice cover which lead to an increase in productivity. The Chaetocerous resting spore data suggests that there was a decrease in stratification, which might suggest a decrease in ice melt. Ice was melting prior to the deposition of Sample 3 (ca. 3.2 Ma), at which time the rate of ice melt had decreased.

The Pliocene Epoch spans a time when the Earth experienced a transition from relatively warm conditions to a cooling climate. It was a generally warmer and wetter interval with atmospheric $\mathrm{CO}_{2}$-concentrations at or slightly above modern levels (Pagani et al., 2009, Salzmann et al., 2011). This explains why all three samples are dominated by mostly open ocean and ice tolerant species and gives us a sense of ice sheet dynamics. The size of polar ice sheets might have been significantly reduced during the Pliocene causing ca. $25 \mathrm{~m}$ higher sea levels than today and serves as an analog to future climate conditions (Dowsett et al., 2010). However, the consistently high abundance of Eucampia Antarctica, a species with a higher affinity for sea ice, ensures that sea ice was, in fact, consistently present through this time interval.

\section{CONCLUSION}

To explore the relationship between sea surface conditions and ice cover variability in a sensitive location off of East Antarctica, we have initiated a diatombased paleo environmental reconstruction of Site 697 in the mid-Pliocene. Our data indicate the area was influenced by sea ice but was marked by open ocean conditions through 3.2-3.29 Ma. Fluctuating percentages of open ocean diatoms indicate ice conditions were unstable during this 100,000 year period.

A more comprehensive dataset will allow us to gather paleoenvironmental data through Cores 14-17X. This 
will allow us to explore conditions, not only during MIS M2, but also Turnover Pulse D. We will be able to observe relationship between the two events and discover the mechanisms by which they were catalyzed.

\section{ACKNOWLEDGEMENTS}

This material is based upon work supported by the Keck Geology Consortium and the National Science Foundation under Grant No. 1659322. I would like to thank Professor Suzanne O'Connell for her leadership and mentorship during my KECK experience and throughout my experience as a researcher. I would also like to thank David Harwood for teaching me how to identify diatoms and for his continued support. Lastly, I would like to thank all the members of our research team at Wesleyan University, Melissa Luna, Noah Spriggs, Eliza Carter, and Sophia Ptacek, and my fellow KECK participants, Mark Lapan, Forrest Lloyd, and Andrew Hollyday.

\section{REFERENCES}

Armand LK, Crosta X, Romero O, Pichon JJ, 2005, The biogeography of major diatom taxa in Southern Ocean sediments: 1. Sea ice related species. Palaeogeogr Palaeoclimatol Palaeoecol 223:93-126.

Barker, P.F., Kennet, J.P., Scientific Party, 1988, Weddell sea paleoceanography: Preliminary results of ODP Leg 113: Palaeogeography, Palaeoclimatology, Palaeoecology 67 (1): 75-102.

Crampton, J.S., Cody, R.D., Richard Levy, R., Harwood, D., McKay, R., Naish, T.R., 2016. Southern Ocean phytoplankton turnover in response to stepwise Antarctic cooling over the past 15 million years: Proc. Natl. Acad. Sci. USA 113 (25), 6868-6873.

Chang, Y., 1967. Accuracy of Fossil Percentage Estimation. Journal of Paleontology, Vol. 41, No. 2, p. 500-502.

Crosta X, Romero O, Armand LK, Pichon JJ ,2005, The biogeography of major diatom taxa in Southern Ocean sediments: 2. Open ocean related species: Palaeogeogr Palaeoclimatol Palaeoecol 223:66-92.
Crosta, Xavier and Koç, Nalan, 2007. Diatoms: From Micropaleontology to Isotope Geochemistry, In Hillaire-Marcel, C., and De Vernal, A. (Eds.) Developments in Marine Geology, Proxies in Late Cenozoic Paleoceanography, Vol 1, p. 327358.

Donegan, D., and Schrader, H., 1982, Biogenic and abiogenic components of laminated hemipelagic sediments in the central Gulf of California: Marine Geology, v. 48, p. 215-237, doi: 10.1016/0025-3227(82)90098-6.

Dowsett, H.J., Robinson, M., Haywood, A., Salzmann, U., Hill, D., Sohl, L., Chandler, M., Williams, M., Foley, K., Stoll, D., 2010. The PRISM3D paleoenvironmental reconstruction. Stratigraphy 7, 123-139.

Escutia, C., Brinkhuis, H., and Klaus, A., 2011, IODP Expedition 318: From Greenhouse to Icehouse at the Wilkes Land Antarctic Margin: Scientific Drilling, v. 12, p. 15-23, doi: 10.5194/sd-12-152011.

Gee, J., and Kent, D., 2007, Source of Oceanic Magnetic Anomalies and the Geomagnetic Polarity Timescale: Treatise on Geophysics, p. 419-460, doi: 10.1016/b978-0-444-538024.00106-8.

Given, H. Home: IODP - International Ocean Discovery Program, https://www.iodp.org/aboutiodp/history

Hargraves, P.E., French, F.W., 1975, Observations on the survival of diatom resting spores: Beih. Nova Hedw. v. 53, p. 229-238.

Karpuz, N.K., and Jansen, E., 1992, A high-resolution diatom record of the last deglaciation from the SE Norwegian Sea: Documentation of rapid climatic changes: Paleoceanography, v. 7, p. 499-520, doi: 10.1029/92pa01651.

Lazarus D, Barron J, Renaudie J, Diver P, Türke A, 2014, Cenozoic planktonic marine diatom diversity and correlation to climate change: PLoS One 9(1):e84857.

Leventer, A., 1991, Sediment trap diatom assemblages from the northern Antarctic Peninsula region: Deep Sea Research Part A. Oceanographic Research Papers, v. 38, p. 1127-1143, doi: 10.1016/0198-0149(91)90099-2. 
Leventer, A., Dunbar, R.B., and Demaster, D.J., 1993, Diatom Evidence for Late Holocene Climatic Events in Granite Harbor, Antarctica: Paleoceanography, v. 8, p. 373-386, doi: $10.1029 / 93$ pa00561.

Leventer, A., Domack, E.W., Ishman, S.E., Brachfeld, S., Mcclennen, C.E., and Manley, P., 1996, Productivity cycles of 200-300 years in the Antarctic Peninsula region: Understanding linkages among the sun, atmosphere, oceans, sea ice, and biota: Geological Society of America Bulletin, v. 108, p. 1626-1644, doi: 10.1130/0016-7606(1996)108<1626:pcoyit $>2.3$. $\mathrm{co} ; 2$.

Lisiecki, L. E., and M. E. Raymo, 2005, A PliocenePleistocene stack of 57 globally distributed benthic $\delta^{18} O$ records: Paleoceanography, 20, PA1003, doi:10.1029/2004PA001071

Mann, D., \& Droop, G. (1996). 3. Biodiversity, biogeography and conservation of diatoms. Hydrobiologia, 336(1), 19-32.

Mcquoid, M.R., and Hobson, L.A., 1996, Diatom Resting Stages: Journal of Phycology, v. 32, p. 889-902, doi: 10.1111/j.00223646.1996.00889.x.

Pagani, M., Caldeira, K., Berner, R., and Beerling, D.J., 2009, The role of terrestrial plants in limiting atmospheric $\mathrm{CO}_{2}$ decline over the past 24 million years: Nature, v. 460 , p. $85-88$, doi: 10.1038/nature08133

Salzmann, U., Williams, M., Haywood, A.M., Johnson, A.L.A., Kender, S., Zalasiewicz, J., 2011, Climate and environment of a Pliocene warm world. Palaeogeogr. Palaeoclimatol. Palaeoecol., v. 309, p. 1-8. http://dx.doi. org/10.1016/j.palaeo.2011.05.044.

Tan, N., Ramstein, G., Dumas, C., Contoux, C., Ladant, J. B., Sepulchre, P., Zhang, Z.S., De Schepper, S., 2017, Exploring the MIS M2 glaciation occurring during a warm and high atmospheric $\mathrm{CO}_{2}$ Pliocene background climate: Earth and Planetary Science Letters, v. 472, p. 266-276.

Yool, A., and Tyrell, T., 2003, Role of diatoms in regulating the ocean's silicon cycle: Global Biogeochemical Cycles, v. 17.
Zielinski, U., and Gersonde, R., 1997, Diatom distribution in Southern Ocean surface sediments (Atlantic sector): Implications for paleoenvironmental reconstructions: Palaeogeography, Palaeoclimatology, Palaeoecology, v. 129, p. 213-250, doi: 10.1016/ s0031-0182(96)00130-7. 